\title{
Tabularia
}

\section{The French connection: Some Icelandic translations of French literature in manuscript and print, ca. 1400-1900}

La French connection: quelques traductions islandaises de la littérature française dans les livres manuscrits et imprimés, ca. 1400-1900

La French connection : alcune traduzioni islandesi della letteratura francese in manoscritti e libri a stampa, ca. 1400-1900

\section{Matthew James Driscoll}

\section{OpenEdition}

\section{Journals}

\section{Electronic version}

URL: http://journals.openedition.org/tabularia/3422

DOI: 10.4000/tabularia.3422

ISSN: $1630-7364$

\section{Publisher:}

CRAHAM - Centre Michel de Boüard, Presses universitaires de Caen

\section{Electronic reference}

Matthew James Driscoll, «The French connection: Some Icelandic translations of French literature in manuscript and print, ca. 1400-1900», Tabularia [Online], Autour des sagas : manuscrits, transmission et écriture de l'histoire, Online since 08 February 2019, connection on 02 May 2019. URL : http:// journals.openedition.org/tabularia/3422 ; DOI : 10.4000/tabularia.3422 

The French connection:

Some Icelandic translations of French literature

in manuscript and print, ca. 1400-1900

La French connection: quelques traductions islandaises

de la littérature française dans les livres manuscrits

et imprimés, ca. 1400-1900

La French connection: alcune traduzioni islandesi

della letteratura francese in manoscritti

e libri a stampa, ca. 1400-190o

Matthew James DRISCOLL

Institut for Nordiske Studier og Sprogvidenskab

Københavns Universitet

mjd@hum.ku.dk

Abstract:

The extent of manuscript production in medieval Iceland is well known; less well known is that manuscript transmission remained the norm in Iceland well into the modern era, long after the arrival of the printing press. The range of types of literary works preserved in these manuscripts is vast. Although the bulk of this literature was indigenous and in Icelandic, many works were translated, too, both from Latin and the various European vernaculars. The present essay examines a few of the French literary works that survive in Icelandic translations, both in manuscript and print, from Thomas's Tristan to Jules Verne.

Keywords: Icelandic paper manuscripts, translations, Old Norse-Icelandic literature, rímur, Tristrams saga, Möttuls saga, Chrétien de Troyes, Jean-Pierre Claris de Florian, Voltaire, Les Mille et une nuits, Jules Verne

Résumé:

L'étendue de la production manuscrite dans l'Islande médiévale est bien connue; on sait moins en revanche que la transmission manuscrite est restée la norme en Islande même à l'époque moderne, longtemps après l'arrivée de l'imprimerie. L'éventail des types d'œuvres littéraires conservés dans ces manuscrits est vaste. Bien que la majeure partie de cette littérature soit de production locale et en islandais, beaucoup d'oeuvres ont aussi été traduites soit du latin, soit des langues vernaculaires européennes. Le présent article examine quelques-unes des œuvres littéraires françaises qui subsistent dans des traductions islandaises, à la fois dans des manuscrits et des imprimés, depuis le Tristan de Thomas jusqu'à l'œuvre de Jules Verne.

Mots-clés: manuscrits islandais, traductions, littérature islandaise, rímur, Tristrams saga, Möttuls saga, Chrétien de Troyes, Jean-Pierre Claris de Florian, Voltaire, Les Mille et une nuits, Jules Verne

Riassunto:

L'estensione della produzione di manoscritti nell'Islanda medievale è ben nota; meno noto è che la trasmissione manoscritta sia rimasta la norma in Islanda fino all'età moderna, molto tempo

Tabularia "Études», "Autour des sagas... », 2019, p. 1-24, 8 février 2019 URL: http://journals.openedition.org/tabularia/3422 | DOI : 10.4000/tabularia.3422 
dopo l'arrivo della stampa. La gamma di tipi di opere letterarie conservate in questi manoscritti è vasta. Sebbene la maggior parte di questa letteratura fosse autoctona e in islandese, molte opere furono tradotte, inoltre, sia dal latino che dai vari vernacoli europei. Il presente articolo esamina alcune delle opere letterarie francesi che sopravvivono nelle traduzioni islandesi, sia in manoscritti che in libri a stampa, dal Tristan di Thomas alle opere di Jules Verne.

Parole chiave: manoscritti islandesi, traduzioni, letteratura islandese, rímur, Tristrams saga, Möttuls saga, Chrétien de Troyes, Jean-Pierre Claris de Florian, Voltaire, Les Mille et une nuits, Jules Verne

\section{Introduction $^{1}$}

Iceland - nowadays probably best known for its glaciers and volcanos, its financial crisis and its lively music scene - also has a long history as a hotbed of literary activity, starting with the Eddas and sagas of the medieval period and extending to the crime fiction of the present day. For most of Iceland's history, this literature circulated predominantly in handwritten form, as manuscripts, initially on vellum, later on paper. Indeed, for certain types of literature at least, manuscript transmission remained the norm in Iceland well into the modern era, long after the arrival of the first printing press in the mid-sixteenth century ${ }^{2}$.

The range of types of literature preserved is vast, from sombre works of religious devotion to romping romances and tales of derring-do. Although Latin learning was certainly not unknown in Iceland, the bulk of this literature was in Icelandic, and was the product of the indigenous Icelandic imagination. But many works were translated, too, both from Latin and the various European vernaculars, not least French ${ }^{3}$. The Icelanders' appetite for good stories was voracious, and it is clear that pretty much anything that was known on the continent was likely eventually to find its way to Iceland. In the present essay, I will examine a selection of the French literary works that survive in Icelandic translations, primarily handwritten but some also in print, the routes by which they travelled there and their later fates in Iceland once they were there ${ }^{4}$.

\section{The medieval legacy: From romans courtois to riddarasögur}

The culture of the book came to the north with Christianity, and among the first things to be translated were works which served the needs of the Church, such

1. This article is based on the keynote lecture I gave at the $I I^{e}$ congrès de l'Association pour les études nordiques (APEN), Caen, 15 June 2017.

2. On the relationship between manuscript and print in Iceland, and the reasons for the longevity of chirographic transmission, see DrISCOLL, 2013 and ÓlafsSON, 2017.

3. A preliminary list of Icelandic translations and adaptations from French is found in PORGILSSON, 1954 .

4. The selection of texts treated here has not been made on any scientific basis; rather I have chosen those texts among those I have encountered in the course of my research which I have found the most interesting. I believe, however, that they are representative of the kinds of material translated. 
as saints' lives, homilies and so on, the bulk of which were translated from Latin. As the native literature began to emerge in the second half of the twelfth century, so too did translations of secular works begin to appear, both from Latin and, increasingly as time went on, vernacular languages.

About twenty Old Norse-Icelandic ${ }^{5}$ translations of European courtly romance, most of them from French, survive from the medieval period. These translations, known as riddarasögur (lit. sagas of knights) ${ }^{6}$, are for the most part thought to have been made in Norway, but nearly all survive chiefly or exclusively in Icelandic copies? ${ }^{7}$.

\section{Tristrams saga ok Ísöndar}

The earliest of these is likely to be Tristrams saga ok Ísöndar (The saga of Tristram and Ísönd), a translation of the romance Tristan by the twelfth-century Anglo-Norman poet Thomas of Britain, produced, according to the prologue, by one "Bróðir Róbert" (Brother Robert) in 1226 at the behest of King Hákon Hákonarson of Norway (r. 1217-1263).

Tristrams saga survives in eight manuscripts, all of them Icelandic. There are two vellum fragments from the late fifteenth century, while the rest are paper manuscripts from the seventeenth and eighteenth centuries. The oldest Tristrams saga manuscript to preserve the prologue containing the attribution to Brother Robert is Copenhagen, Arnamagnæan Collection, AM 543 4to (fig. 1), a paper manuscript dated to the seventeenth century. The prologue reads as follows:

Hier skrifast Sagann af Tristram og Jsónd Drottningu j hvórri talad verdur umm Obcrelega Ast er pau hófdu sijn a Millumm. Var pä lided frä hingadburde Christi 1226 Aar, er pessi Saga var a Norrenu skrifud, epter befalningu og skipan Virduglegs herra Hakonar kongz. En Broder Robert efnade og uppskrifade epter sinne kunnattu, med pessum Ordtökumm sem epterfilger i Sógunni. og nu skal fra seigia.

(Written down here is the story of Tristram and Queen Ísönd, in which is told about the unbearable love they had between them. 1226 years had passed since the birth of Christ when this saga was translated into Norse at the behest and order of the venerable King Hákon. Brother Robert prepared the text and wrote it down according to his knowledge in the words appearing in this saga, and now it shall be told. $)^{8}$

5. 'Old Norse-Icelandic' denotes the common language of Norway and Iceland (and the Faroe Islands, Orkney, Shetland and the Norse settlements in Greenland) in the Middle Ages. The two languages, Icelandic and Norwegian, began to diverge in the fourteenth century.

6. The same designation is applied to slightly younger indigenous Icelandic works which were written, at least in part, in imitation of these translated romances and take place in a courtly milieu; they are sometimes also referred to as lygisögur (lit. lying sagas); see DrIsColL, 2005.

7. On these translated romances see e.g. MACleAN, 1972, KALINKE, 1985, BARNES, 1993, ThORLEIFSDótTIR, 2004, 2007, GLAUSER, 2005, ERIKSEN, 2017.

8. All translations in the present article are by the author. 


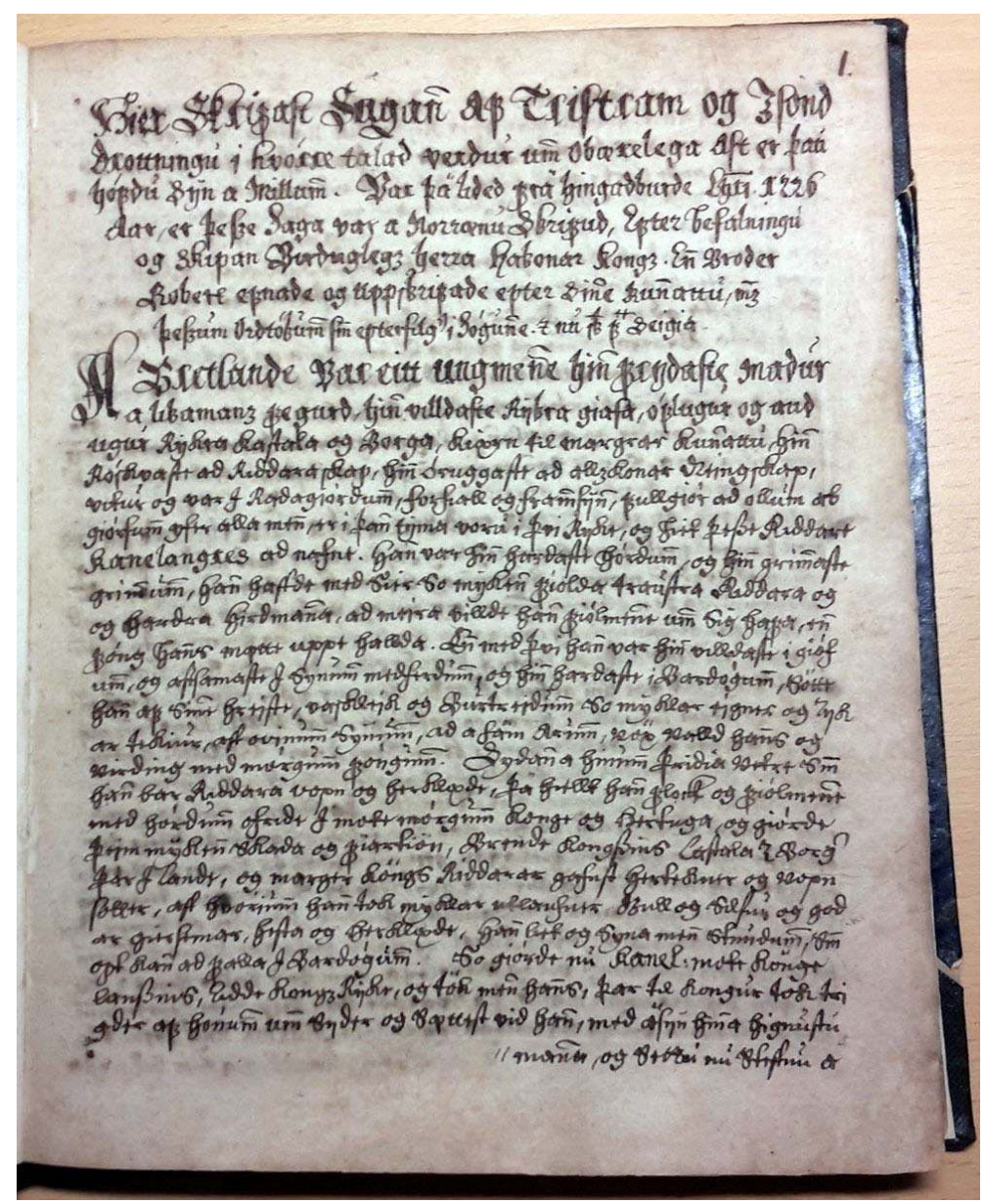

Fig. 1: Copenhagen, Arnamagnæan Collection, AM 543 4to, f. 1r, the beginning of Tristrams saga og Îsöndar, copied in the seventeenth century

Owing to his name - and his obvious familiarity with Norman French - it has been suggested that "Bróðir Róbert" may have himself been a Norman, who had however become fluent enough in Old Norse to be able to translate into that language. Elis saga ok Rósamundu, a translation of the French romance Elie de Saint Gille, is similarly attributed to a "Róbert ábóti" (Abbot Robert), presumably the same man now further advanced in his ecclesiastical career ${ }^{9}$.

Tristrams saga has received a good deal of scholarly attention, both as it is the most complete representative of Thomas's Tristan extant and also owing to its assumed position as the earliest of the Old Norse translations of French

9. Sснасн, 1975. The suggestion that these translations were the work of one and the same man goes back to nineteenth-century scholars such as Rudolf Keyser, C.R. Unger, Gísli Brynjúlfsson and Eugen Kölbing. 
romances ${ }^{10}$. It is also thought to have exerted considerable influence on Old Norse-Icelandic narrative literature. The theory has had few supporters, but it was even suggested, by the Danish scholar Paul Rubow in the early part of the last century, that it was Brother Robert's Tristrams saga that kick-started Old Norse-Icelandic saga writing in general: "Der burde et Sted oprejses ham en Statue, thi han er efter al Sandsynlighed Grundlogger af den oldnordiske Underholdningslitteratur i Prose" (There ought to be erected a statue to him somewhere, for he is in all probability the founding father of Old Norse prose fiction) $)^{11}$. Motifs ostensibly deriving from Tristrams saga have been identified in Rémundar saga keisarasonar, Haralds saga Hringsbana - which Margaret Schlauch thought "seem[ed] to have been constructed as a deliberate reply to the French romance" 12 - Jarlmanns saga ok Hermanns and several other romances, and also in "Spesar páttr", the final section of Grettis saga. Similarly, alleged influence from the Tristan story has been detected in the four so-called skáldasögur, or "poets' sagas", Kormáks saga in particular, to such a degree that Bjarni Einarsson, for example, could refer to Kormákr as "Tristan Íslands" (the Icelandic Tristan ${ }^{13}$. Recently, however, a number of scholars, Alison Finlay foremost among them ${ }^{14}$, have rejected the idea that there are any narrative correspondences between Tristrams saga and the poets' sagas, and the whole question of the saga's position and influence may be said to be ripe for reassessment.

From the same period, the mid-thirteenth century, are translations of three of the five romances attributed to Chrétien de Troyes (late twelfth century): Erex saga (Érec et Énide), Ívens saga (Yvain, le Chevalier au Lion) and Parcevals saga, with Valvens páttur ${ }^{15}$ (Perceval, le Conte du Graal). The translations are all thought to date from the mid-thirteenth century, and all, like Tristrams saga, are believed to have been made at the behest of King Hákon Hákonarson ${ }^{16}$; in the case of Ivens saga, this is explicitly stated in the epilogue. As with most material of this sort, texts of these translations survive only in copies made in Iceland. Ivens saga and Parcevals saga are both found in fifteenth-century vellums, but these are defective, so the only complete texts are younger, and Erex saga survives only in paper copies from the seventeenth century and later ${ }^{17}$.

All of these translations suffer from textual attrition vis-à-vis their French sources, on average a reduction of $40-60 \%$. It is difficult to know at what stage this attrition took place, i.e. whether at the time of translation or later in the

10. For a survey of this, see BARNEs, 2011.

11. Rubow, 1936, p. 21.

12. Schlauch, 1934, p. 151.

13. EINARSSON, 1961, p. 163.

14. FINLAY, 2004.

15. The part of the saga dealing exclusively with Gawain was at some point separated from the rest and treated as a separate, if related, work, Valvens páttr, páttr (lit. 'strand') being the Old Norse term for a short tale within a larger narrative.

16. See e.g. LEACH, 1921, p. 149-157.

17. The scholarly literature on these translations is extensive; for surveys see BoRNHOLDT, 2011; KALINKE, 2011. 
course of transmission, though, on the whole, the latter seems more likely ${ }^{18}$. Typically, descriptions of equipment, clothes and horses are reduced or removed, as are expressions of inner conflict by the protagonists on the nature of love and honour and any first person commentary by the narrator - in short, much of what may be said to characterise Chrétien's romances.

\section{Möttuls saga and Skikkjurímur}

Apparently also from the time of King Hákon Hákonarson is Möttuls saga (The saga of the mantel), a translation of La mantel mautaillé (also known as Le Lai du cort mantel), a somewhat frivolous tale of a chastity testing mantle sent to King Arthur's court, dating from the end of the twelfth century or the beginning of the thirteenth (there are vellum manuscripts from the fourteenth and fifteenth centuries) ${ }^{19}$.

It has been suggested that Möttuls saga may have been, after Tristrams saga ok Ísöndar, the earliest of the Arthurian romances to be translated into Old Norse-Icelandic. Among the evidence adduced for this is the presence in the saga of a long introductory section describing King Arthur in the most glorious terms. This section has no parallel in the French original - and indeed would have been quite out of place there - but, it has been argued, would have been necessary to bring a Norwegian audience unfamiliar with the figure of King Arthur up to speed. The misnaming for example of Parceval as Paternas and Yvain/Íven as Meon in the saga has also been cited as evidence for an early date ${ }^{20}$.

The saga's transmission history is complicated. There are two branches, both represented by late medieval (fourteenth-century) vellum fragments and paper copies from the seventeenth to the nineteenth centuries. Here again, all the manuscripts are Icelandic.

In Iceland, Möttuls saga, in turn, became the basis for Skikkjurimur (Mantle verses), composed probably in the fifteenth century, the only Icelandic rimur to deal with an Arthurian theme (fig. 2). Rimur - long metrical romances in complex metres making use of both alliteration and end-rhyme - were almost invariably based on pre-existing prose narratives ${ }^{21}$. While most rimur follow their sources quite closely, even slavishly, Skikkjurimur are unusual in that, although the basic plot of Möttuls saga remains unchanged, there are both lengthy additions and significant omissions. The effect of these is to increase even further the burlesque element of the story, at the expense of any serious critique of courtoisie which underlies the humour of La mantel mautaillé $e^{22}$.

18. KaLINKE, 2011, p. 32-37.

19. Discussions of Möttuls saga can be found in KaLinke, 1981, Driscoll, 1991, Larrington, 2011, p. $85-89$.

20. Kalinke, 1987, p. lviii-lxi. The suggestion that Möttuls saga was the first romance dealing with King Arthur to be translated was first made by CEDERschiöLd \& WULfF, 1877, p. 93.

21. On rimur in general see Hughes, 2005, and references there.

22. Skikkjurímur are discussed in DrisCOLL, 1991, LARRINGTON, 2011, p. 90-93. 


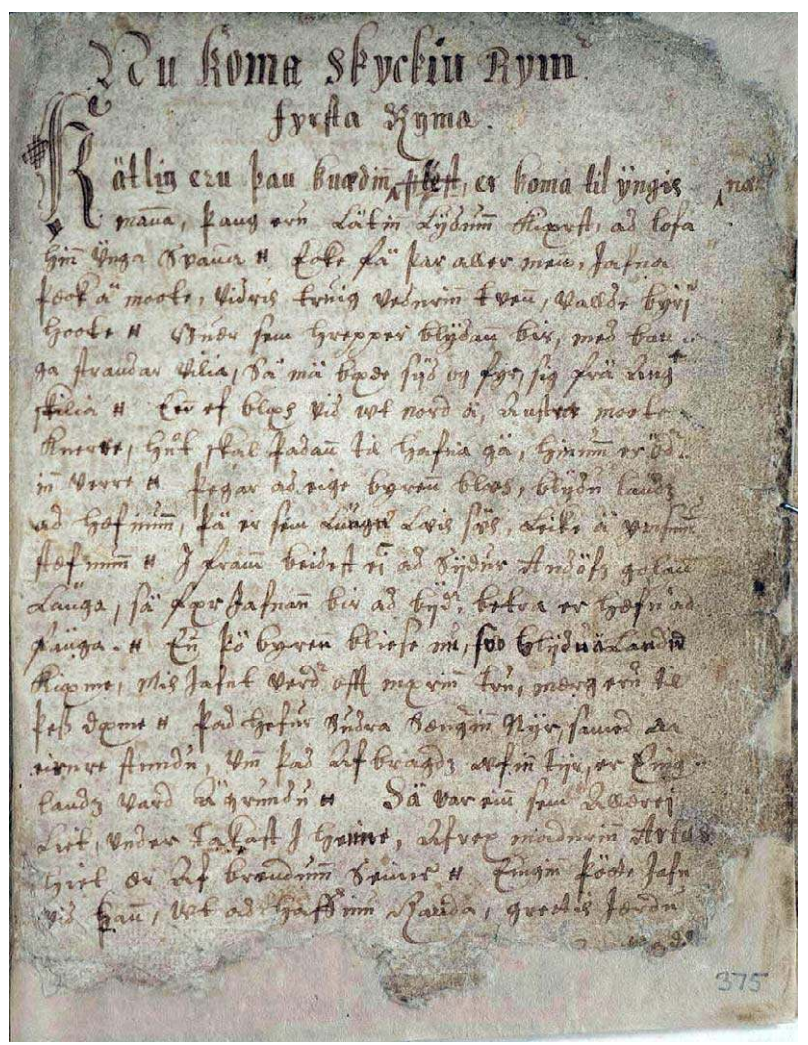

Fig. 2: Reykjavík, Árni Magnússon Institute, Acc. 22, f. 187r, the beginning of Skikkjurímur, copied in 1695 by Jón Pórðarson

A reference to Arthur's kringlótt sess, "round seat" - not mentioned in Möttuls saga - indicates that the poet had some notion of the existence of the famous round table, first described in Wace's Roman de Brut (1155), otherwise scarcely mentioned in early Icelandic sources ${ }^{23}$.

\section{The Afterlife of Tristan in Iceland}

In addition to the Old Norse-Icelandic Tristrams saga ok Ísöndar, mentioned above, there is a younger Saga af Tristram ok Isodd (the Saga of Tristram and Ísodd), an original Icelandic composition of the fourteenth century, distinct from the thirteenth-century translation of Brother Robert. It is preserved in a single fifteenth-century vellum and four paper manuscripts from the eighteenth and nineteenth centuries. Although presumably derived from the older saga, the younger Saga af Tristram differs from it markedly. The names of the characters

23. REICHERT, 1986. 
do not always correspond to those in the older saga, and there are significant changes and simplifications to the plot.

This saga has also been the object of a good deal of scholarly attention, much of it focusing on its relation to its apparent source, the older Tristrams saga. Henry Goddard Leach, writing in 1921, thought it to be a vulgarisation, written for a less refined audience: "a boorish account of Tristram's noble passion" 24 . Paul Schach initially deemed it to have been "based on an imperfect recollection of the longer saga, which has been further distorted by the addition of names and situations from other sources" 25 , but later decided, "upon closer scrutiny", that it was "a deliberate caricature of the translated romance" 26 ; Marianne Kalinke went even further, seeing it as a parody not just of Tristrams saga but of Arthurian romance in general ${ }^{27}$.

I tend, I confess, to be rather sceptical of attempts to see irony everywhere, or the assumption that any two works dealing with vaguely similar subjects must be directly related to each other, and only to each other, ideally by one being a parody of the other. When I first read Saga af Tristram ok Isodd it struck me as being a fairly typical late medieval Icelandic romance, no more distorted, exaggerated or vulgar than any other. In the last two decades or so a number of scholars ${ }^{28}$ have argued for the necessity of viewing the younger saga in the literary and cultural context of late mediaeval Iceland, resulting in a far more nuanced view of this highly interesting work.

The story of Tristan also gave rise to an Icelandic ballad. Although the ballad genre was never as popular in Iceland as it was in mainland Scandinavia or the British Isles, some fine examples have been preserved ${ }^{29}$, perhaps none finer than Tristrams kvoedi, thought to have been composed in the fifteenth century. Unlike many of the Icelandic ballads, Tristrams kvoe $i$ has no parallels among the ballads of other traditions and there appears to be no reason to see it as anything other than an original Icelandic composition. Its simple refrain, "Deim var ekki skapað nema (að) skilja" (They were fated only to be parted), seems to capture so beautifully the pathos of the Tristan story ${ }^{30}$.

Several centuries later, a Danish sentimental novel loosely based on the story of Tristan, En Tragoedisk Historie om den cedle og tappre Tistrand, Hertugens Søn af Borgundien, og den skiønne Jndiana, den store Mogul Keyserens Datter af Indien (A tragic story of the noble and valiant Tistrand, son of the duke of Burgundy, and the fair Indiana, daughter of the great mogul, emperor of India), first published in Christiania (present-day Oslo) in 1775 and reprinted at least nineteen times over the next century, also found its way to Iceland, where it was translated into Icelandic six times, both into prose and verse. In this version of the story, a great many changes have been made: the scene of the action has shifted

24. LEACH, 1921, p. 184.

25. SCHACH, 1957-1961, p. 118.

26. SCHACH, 1964, p. 281; this view was first put forward in SCHACH, 1960, and pursued in SCHACH, 1987.

27. KALINKE, 1981, p. 199-202.

28. See in particular Barnes, 1999, Kramarz-Bein, 2000, Francini, 2005.

29. The standard work on Icelandic ballads is Ólason, 1982.

30. On the Icelandic ballad of Tristram see DrISCOLL, 2011, p. 169-71 and references there. 
from Cornwall, Ireland and Brittany to Spain, France and India, and, rather more fundamentally, the two protagonists, Tistrand and Indiana, though fated forever to love only each other, choose not to enter into an illicit sexual liaison. Instead, they agree to limit themselves to simple expressions of affection: Tistrand may kiss her hand, while she will allow herself to stroke him on the cheek ${ }^{31}$.

By far the best known of the Icelandic treatments of this story are the Rimur af Tístrani og Indíonu by Sigurður Breiðförð (1798-1846), the pre-eminent rimurpoet of the nineteenth century. Breiðfjörð composed the rimur in the autumn of 1828 while staying at Helgafell on Snæfellsnes with his uncle, the clergyman Jóhann Bjarnason, who asked his nephew to compose a set of rimur for the entertainment of his household. Finding a copy of the Danish book on his uncle's bookshelf, he decided to use it as the basis for his rimur. Rimur, as was mentioned, are almost invariably based on previously existing prose sources, which the poets tend, by and large, to follow quite closely. Breiðfjörð was rather free with his source, however, skipping over some sections and amplifying others as he saw fit. Not surprisingly, he tended to dwell on the types of scenes generally favoured by rimur-poets: descriptions of sea voyages, feelings of passion and, not least, battles ${ }^{32}$.

Breiðfjörð’s Rímur af Tístrani og Indíonn were printed in 1831 - the first of his rimur to appear in print - but are also found in seven manuscripts, including an autograph (which in fact post-dates the printed text). They are nowadays chiefly known because of an extremely negative review of them written by the naturalist and romantic poet Jónas Hallgrímsson (1807-1845) in the third number of the journal Fjölnir (1837). Jónas takes issue with both the substance and style of Tístrans rímur, but his attack is directed not so much at them in particular as at the entire rímur genre, which he dismisses as simply bad poetry. Although Jónas's review is generally credited with having dealt the rimur their death blow, their popularity continued unabated throughout the nineteenth century ${ }^{33}$.

The youngest of the Icelandic prose versions of the story, called simply Sagan af Tístran og Indiönu, is found in four paper manuscripts, the earliest from 1875, the latest from 1913, all written by the same man, Magnús Jónsson í Tjaldanesi ${ }^{34}$ (1835-1922). Magnús, an ordinary farmer with no formal education, developed early on an interest in collecting and copying manuscripts, and copies, generally more than one, of nearly two hundred sagas are preserved in his hand ${ }^{35}$. Unlike the other prose versions, Magnús's Sagan af Tístran og Indiönu

31. This little known but highly interesting manifestation of the Tristan story is discussed in KaLINKE, 1991, KJÆR, 1994, DRISCOLL, 2011, p. 182-187.

32. See KJÆR, 1996, DrisCOLL, 2011, p. 188-191.

33. DRISCOLL, 2011, p. 189-19o.

34. Traditionally, most Icelanders do not have surnames, but rather a patronym, ending in '-son' for men and '-dóttir' for women; this is not really a name, but rather a description, so Icelanders are normally referred to (and listed) by their first names. It was also common to refer to people by the place they lived or came from, using the appropriate preposition and the name of the place in the dative: Magnús Jónsson í Tjaldanesi, from the farm Tjaldanes in Dalasýsla, western Iceland. Where Icelanders have adopted surnames practice varies. Sigurður Breiðförð, for example, was often referred to by his contemporaries as 'Breiðfjörð'.

35. On Magnús and his scribal activity see DrISCOLL, 2012. 
is not derived directly from the Danish novel, but is in fact a prose retelling of Sigurður Breiðförð’s rimur. The phenomenon of recasting in prose rímur which were themselves based on prose sagas was commonplace, and may perhaps be compared to the relationship between, say, the books and films dealing with Harry Potter. Both versions tell essentially - but not necessarily entirely - the same story, only the medium is different.

The story of Tristan was thus known in Iceland for seven centuries, from the very beginnings of saga writing in the early thirteenth century to its very end in the early twentieth. Following its development, we can see how this quite simple story of two people who, through no fault of their own, were "fated only to be parted", was constantly reinvented over time, in widely differing genres, to suit the changing needs and tastes of successive audiences.

\section{Florian's Numa Pompilius and Sélico}

Sigurður Breiðfjörð composed another set of rímur several years later based on material which also has its roots in France. These are his Rimur af Núma Pompilssyni, based on the novel Numa Pompilius, second roi de Rome by JeanPierre Claris de Florian (1755-1794), published in Paris in 1786. Scarcely known today, Florian was a popular author of novels, comedies and, in particular, fables, which were translated into all the languages of Europe. His historical novel Numa Pompilius appeared in Danish translation in 1792 as Numa Pompilius, Roms anden Konge. Núma rímur, composed in 1833, are based on this Danish translation. Breiðförð had studied cooperage in Copenhagen and worked as a cooper in Greenland for a time. It was while in Greenland, suffering from scurvy, that he composed his Numa rimur, which are widely regarded as the best of Breiðfjörð's rímur ${ }^{36}$.

Breiðfjörð sticks to his source quite closely in most places, but does occasionally abridge or omit entirely episodes or details, especially those which are not directly relevant to the main plot. He also makes several additions, including three lengthy battle descriptions which have no parallel in the original and a detailed description of a battle field: these are staples of the rimur and so Breiðfjörð presumably felt compelled to include them.

Núma rimur are found in an autograph manuscript, Reykjavík, National and University Library of Iceland, ÍB 304 4to (fig. 3), which was used as the basis for the first printed edition, which appeared in 1835 . The rimur have been printed a further three times, in 1903, 1937 and 1963, something of an achievement even by Breiðfjörð's standards ${ }^{37}$.

36. For more information on Sigurður Breiðfjörð and Núma rímur, see the introduction to SiguRJónsSON, 1937.

37. 26 sets of rímur by Sigurður Breiðförr have survived, of which ten were printed during his lifetime, more than by any other poet. We know of at least a further six sets which have not survived; see SIGMUNDsson, 1966, II, p. 124-125. 


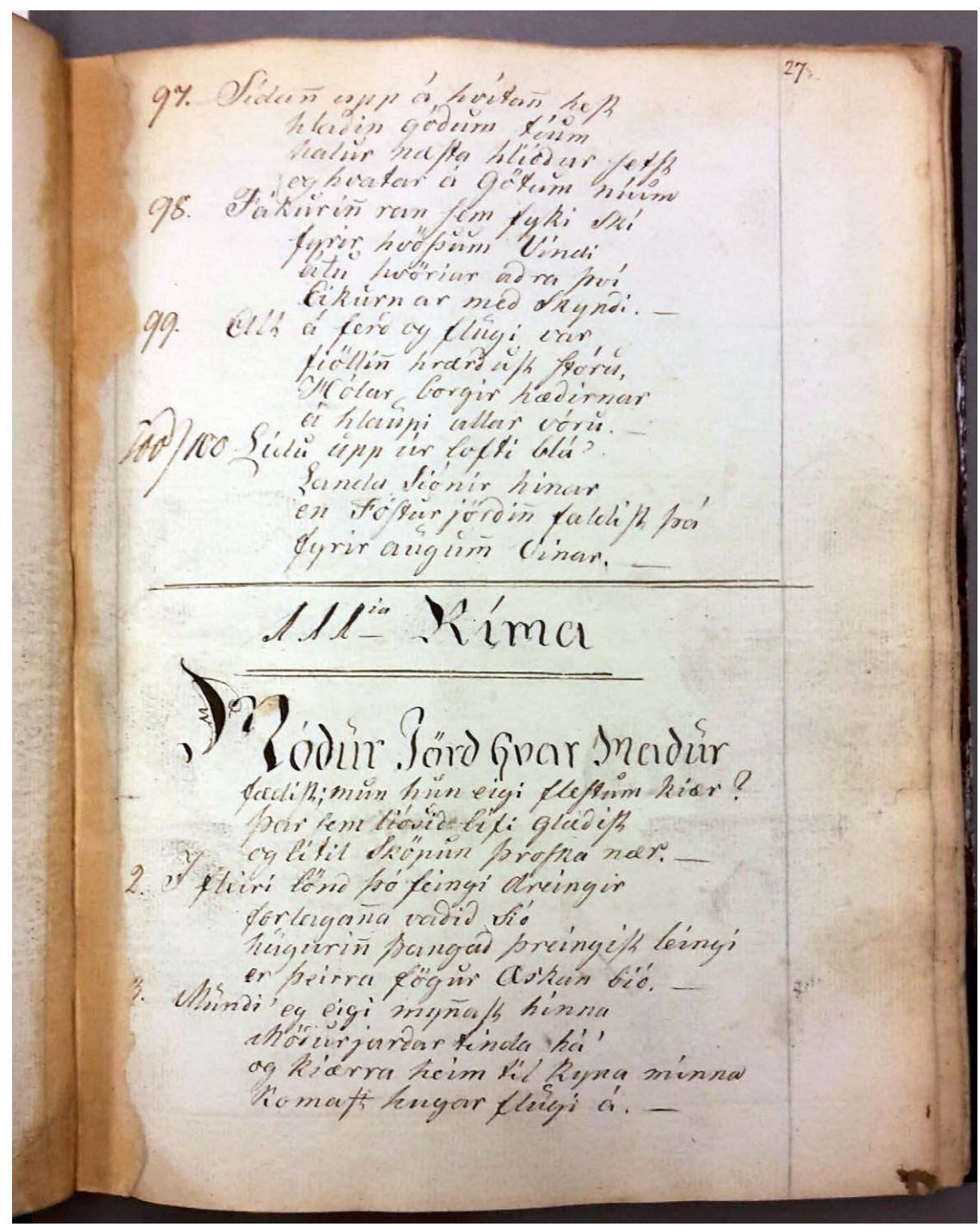

Fig. 3: Reykjavík, National and University Library of Iceland, ÍB 304 4to, f. 27r, the beginning of the third fit of Rímur af Núma Pompilssyni by Sigurður Breiðförð (autograph)

A prose version of the story, Sagan af Núma Pompilssyni, konungi Rómverja, is, like Sagan af Tístran og Indiönu, found in four paper manuscripts by Magnús Jónsson í Tjaldanesi. The earliest of these is undated but probably from the 1860 s, while the latest, Reykjavík, National and University Library of Iceland, Lbs 1505 4to, is written in 1900 (fig. 4). In a preface to this youngest manuscript Magnús says that he originally borrowed his exemplar from Kristján Magnússon á Kornsá in 1862. Kristján had copied the saga himself while at the fishing station 


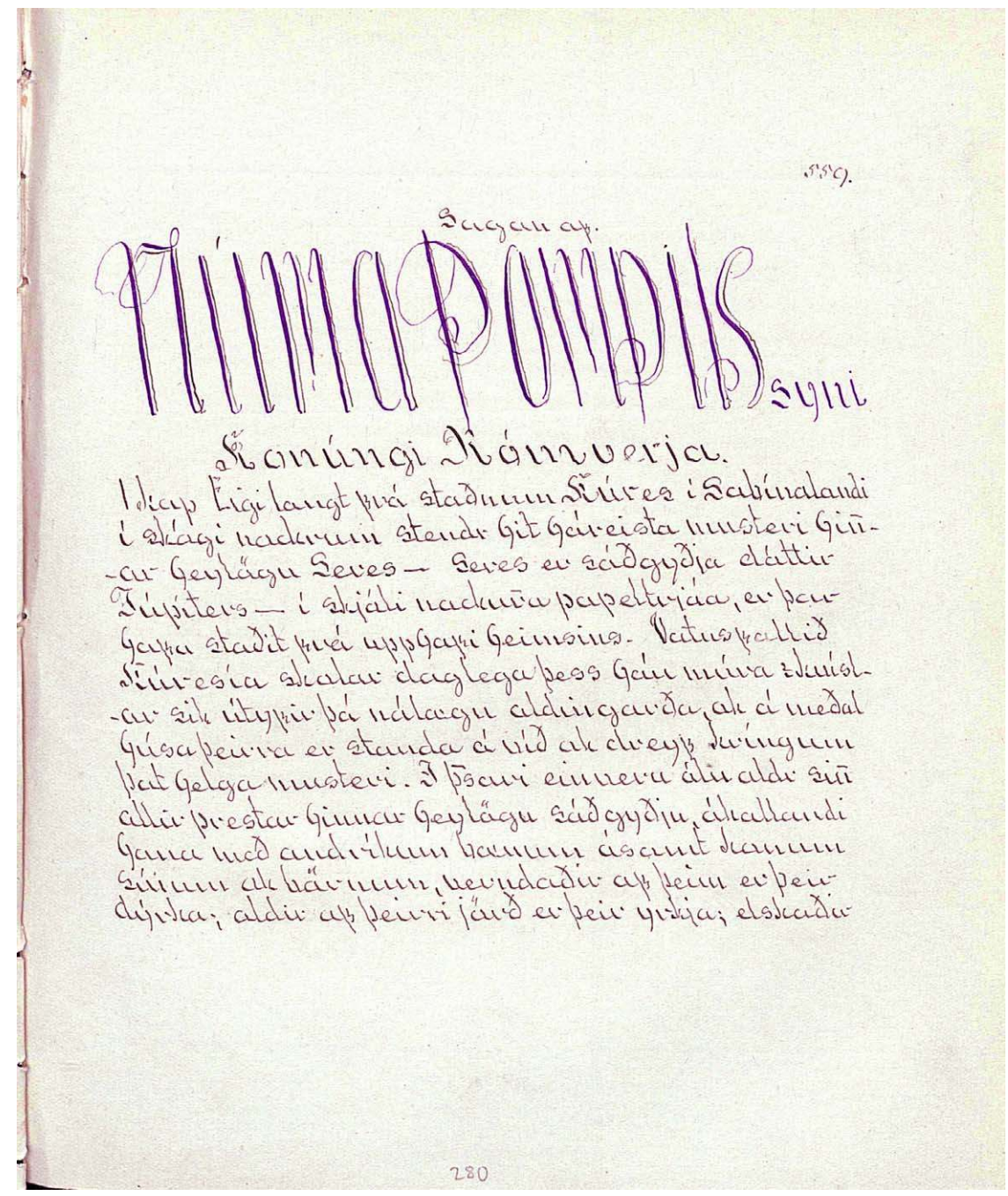

Fig. 4: Reykjavík, National and University Library of Iceland, Lbs 1505 4to, f. 28or, the beginning of "Sagan af Núma Pompilssyni, konúngi Rómverja", copied in 1900 by Magnús Jónsson í Tjaldanesi

in Gjögur, although he couldn't remember what manuscript he had copied it from. Magnús says that he was later able to get hold of a copy of the saga owned (and possibly written) by Kristián Ívarsson (1830-1900). The text was essentially the same as his, he says, but he could not be sure whether this had been the exemplar used by Kristján Magnússon. A fifth manuscript of the saga, a late nineteenth-century copy in an unknown hand, bears the title "Sagan af Núma konungi Pompilssyni. Îslenskuð af Kristjáni fræðimanni Ívarssyni” (The saga of King Númi Pompilsson, Icelandicised by the scholar Kristján İvarsson), which 
can only mean that the translation is by Kristján himself. Whether this was the copy used by Kristján Magnússon remains to be determined.

Unlike the prose Sagan af Tístran og Indiönu mentioned above, this version is not a "prosification" of Sigurður Breiðfjörð's rimur, but a translation of the Danish translation of Florian's novel. It must, however, post-date the composition of the rimur, certainly if it is true that the translation is by Kristján Ívarsson, who was born in 1830 and would have been only three years old when the rimur were composed. The impetus for translating the saga presumably came from the great popularity of the rimur ${ }^{38}$.

Another of Jean-Pierre Claris de Florian's works also found its way to Iceland. This was the novella "Sélico: Nouvelle Africaine", published in 1792 in the collection Nouvelles Nouvelles. The story, a contribution to the debate on the abolition of slavery, tells of a young Guinean, the virtuous Sélico, the youngest of three sons of the widow Darina. On the evening of his wedding to his beloved Bérissa, daughter of the high priest of their tribe, their lands are attacked by a rival tribe, the ferocious Dahomians. Driven from their home, and believing his beloved to have been killed, Sélico arranges to have himself sold into slavery by his brothers in order to save their mother from starvation. At the slave-market, however, they learn that the king of the Dahomians is offering an enormous reward for the head of the man who invaded his seraglio and spent the night with his newest concubine. Sélico pretends to be this intruder, and is condemned to death. It emerges, however, that the concubine, who also is to be put to death, is none other than the still chaste Bérissa, and the intruder her father. The king, moved by Sélico and Bérissa's virtue and selflessness, pardons them, and everyone lives happily ever after.

"Sélico" was translated into Icelandic by Hallgrímur Scheving (1781-1861), teacher and headmaster at the Latin school at Bessastaðir (from 1846 in Reykjavík), as "Selikó (Afrikanisk frásaga)", and printed in the second volume of Margvíslegt gaman og alvara (Assorted jocularity and seriousness), which appeared in 1818, twenty years after the first volume, which had been published in 1798 (fig. 5). Hallgrímur Scheving was one of the most learned Icelanders of his day, an inspiring teacher, a great promoter of the Icelandic language and one of the precursors of the Icelandic national-romantic movement of the nineteenth century ${ }^{39}$. It is not clear why he should have chosen precisely this story to translate, but presumably he found it edifying and thought it would appeal to his countrymen. If so, he was right.

The story is also found in a number of hand-written copies, based on this printed edition, two of them by the previously mentioned Magnús Jónsson í Tjaldanesi. Hallgrímur's translation was reissued as a book for children, complete with illustrations, as Selíkó: Svertingjasaga með myndum (lit. Seliko: A negro-story with pictures), published in the north Icelandic town of Akureyri in 1926 and reissued in 1949 (fig. 6).

38. SigurJónsson, 1937, p. xxiii.

39. On Hallgrímur Scheving see GuĐmundsson, 1969. 


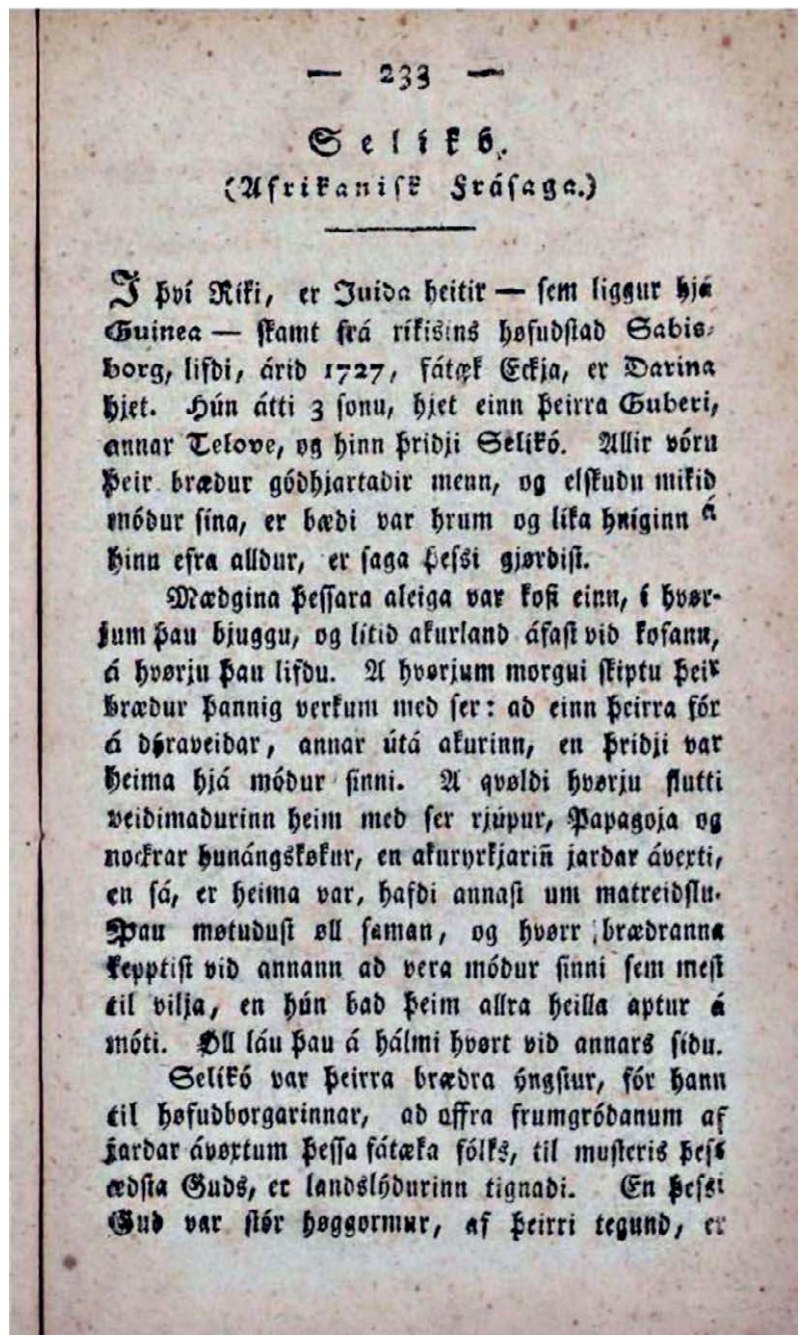

Fig. 5: “Selíkó (Afrikanisk frásaga)”, Margvíslegt gaman og alvara II (1818)

There are also two sets of rímur based on the novel: one, Rímur af Selikó og Berissu by Sigfús Jónsson á Laugalandi (1785-1855), which were composed in 1823 and are preserved in six manuscripts, and another with the same title composed in 1840 by Hallgrímur Jónsson (1787-1860). These latter were published by the press in Viðey in 1844 as Efintýrid af Selikó og Berissu, tilfallid árid 1727. Snúid úr Frønsku máli a Jslendsku af Dr. Hallgrimi Scheving. En á Ljódmoeli snúid af Hallgrimi Jónssyni 1840. Nokkud aukid af Landaskipunararfroedinni, og peim Fetisku trúarbrøgdum Sudurálfunnar, til frekari upplísingar fyrir fáfródari (The adventures of Seliko and Berissa, which took place in 1727. Translated from the French language into Icelandic by Dr. Hallgrímur Scheving and rendered into verse by Hallgrímur Jónsson in 1840. Somewhat augmented concerning 


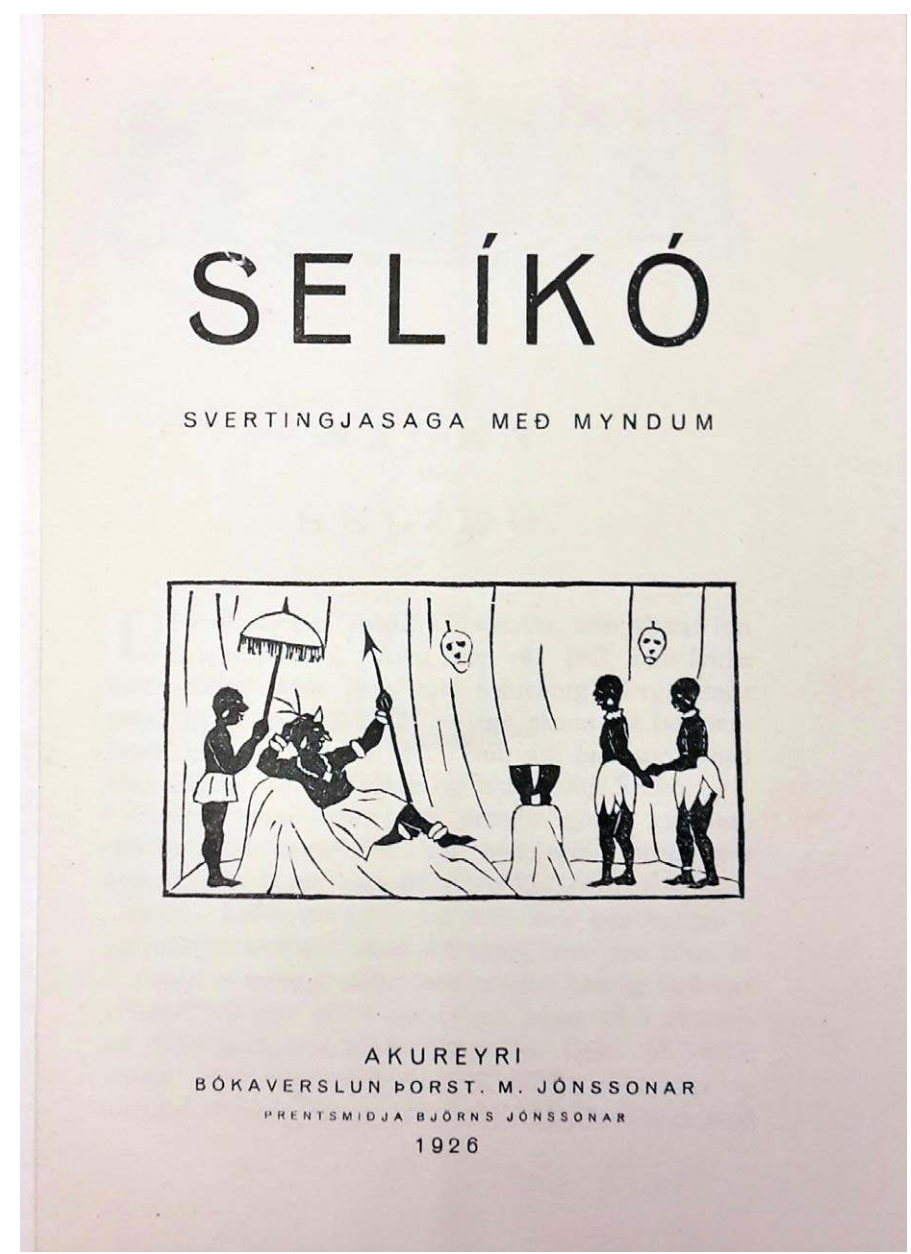

Fig. 6: Selíkó: Svertingjasaga með myndum (Akureyri, 1926)

the geography and fetishist religious beliefs of the southern hemisphere for the further enlightenment of the less well informed). They are also found in five manuscripts, including one autograph, all post-dating the printed edition.

This was clearly a story with which anyone in nineteenth-century Iceland was likely to have been familiar in one form or another.

\section{Contes orientaux}

Although not French as such, the collection of oriental tales translated and adapted by Jean-Antoine Galland (1646-1715) as Les Mille et une nuits made this wealth of material available to the European reading public through the medium of French. First published in twelve volumes in Paris between the years 1704 and 1711, Les Mille et une nuits was quickly translated into most other European 
languages. Although not initially printed, translations of the collection also found their way to Iceland, circulating in manuscript. There are in fact three separate Icelandic translations of all or part of the collection, all based on the Danish translation of $1746^{40}$.

The earliest version is from the second half of the eighteenth century and may be by the clergyman Árni Gíslason að Stafafelli (1755-1840). Shown here is the title page of the second of the three translations, preserved in Reykjavík, National and University Library of Iceland, Lbs 1655 4to (fig. 7), entitled "Skémtilegar og Lystilegar Frásagnir sem kallast Púsund og Ein Nótt Eptir Islendskum Útleggingum Prestanna Peturs og Jóns Uppskrifaðar ad Fiardarhorni vid Hrútafiörd og innbundnar Árid 1816" (Entertaining and exquisite narratives which are called the Thousand and one nights, from the Icelandic translation of the clergymen Pétur and Jón, copied at Fjarðarhorn on Hrútafjörður and bound together in the year 1816). The two clergymen referred to are Pétur Björnsson from Tjörn on Vatnsnes (1723-1803) and Jón Guðmundsson at Melstaðir (1730-1814). The manuscript was written by Sigurður Sigurðsson (1763-1826) and two of his sons, Matthías and Ólafur, who both took the name Sivertsen. The third version was written in 1830-40. The title page to this one makes the entire transmission history explicit: "Ein Nótt og Púsund [...] fyrst ur Arabisku út lögd á Frönsku af Monsr. Galland [...] prickt i Kaupmannahöfn 1746 [...] Enn nú á Jslendsku snúinn af Jóni Porsteins syni" (The thousand and one nights, first translated from Arabic to French by M. Galland, printed in Copenhagen in 1746 and now rendered into Icelandic by Jón Porsteinsson). The translator, Jón Porsteinsson (1795-1848), was a farmer at Krákustaðir.

Two selections from the 1001 Nights were printed in 1835 and 1852 and a complete translation by Steingrímur Thorsteinsson (1831-1913), headmaster of the Latin school in Reykjavík, appeared in 1857-64 (revised edition 1910-12).

A similar collection of Persian tales was translated by François Pétis de la Croix (1653-1713) and published in five volumes as Les Mille et un jours, contes persans in 1710-1712. Although less well known today than the 1001 Nights it was highly popular in its day - one of its tales, the fourth one, that of Calaf, served as the source for Puccini's opera Turandot. Given its popularity, the collection also inevitably found its way to Iceland, where it was translated into Icelandic in whole or in part five times ${ }^{41}$. The first of these, made sometime before 1770, was from the English translation of Ambrose Phillips, published in 1714; although only found in a manuscript from 1840, this translation must have been made before 1770 , as it served as the basis for a set of Rimur af Refsimu by Páll Sveinsson, which were composed in that year and are based on the nineteenth and final tale in the collection, which tells of the virtuous Repsima, falsely accused of adultery by her brother-in-law, whose advances she had spurned. The other four translations

\footnotetext{
40. There has been no full study of these translations, but they are treated briefly in SveInsson, 1929, p. Ixx; Hermannsson, 1942, p. 57-58; Driscoll, 1997, p. 9-10.

41. On this material see STEINGRÍmSSON, 1980.
} 


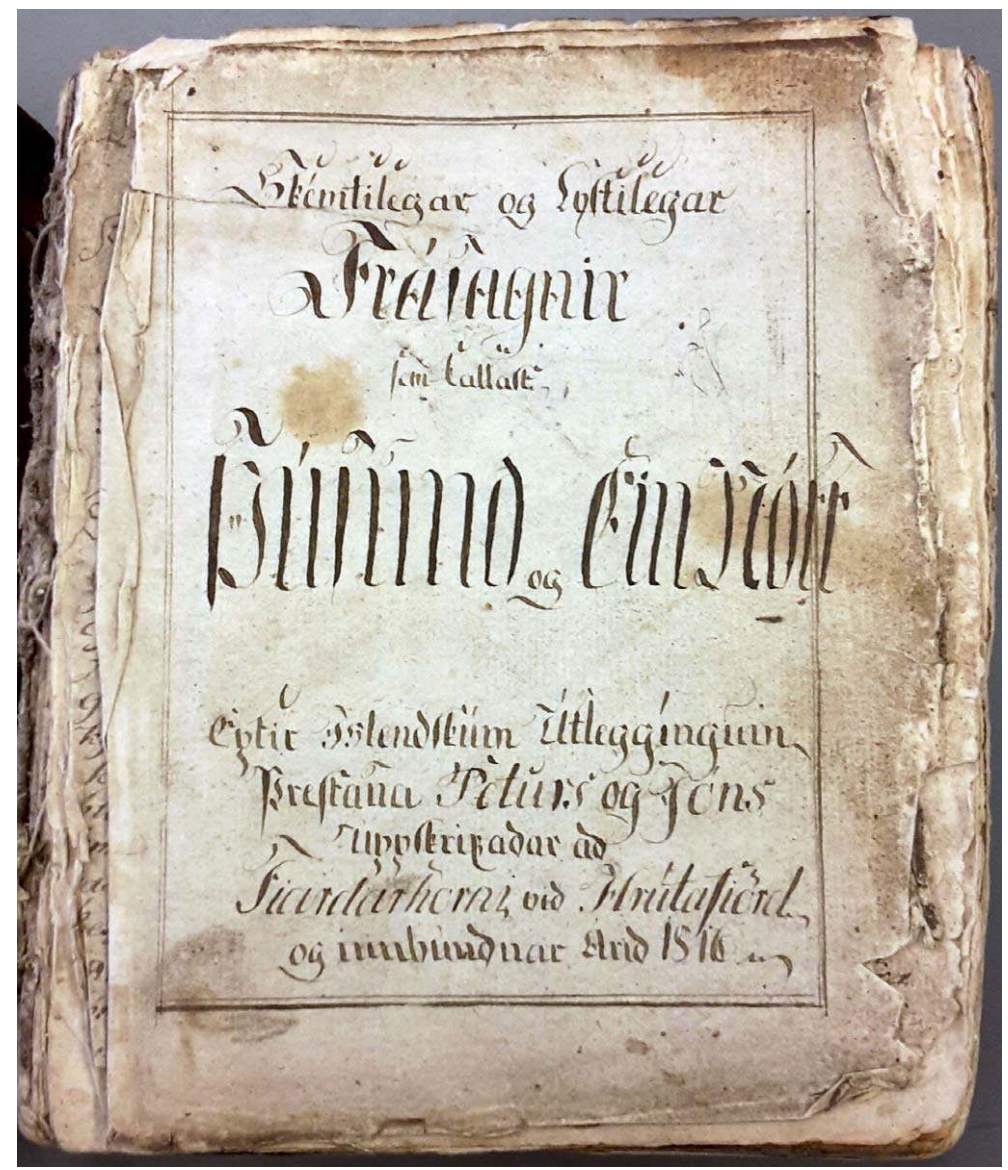

Fig. 7: Reykjavík, National and University Library of Iceland, Lbs 1655 4to, title page of a translation of Les Mille et une nuits, copied in 1816

were all from the Danish translation of 1759. The five translations are preserved in fourteen manuscripts altogether. The last of them, which is only of the fourth tale, the source of Turandot, was made by Steingrímur Thorsteinsson, who had also translated the entire 1001 Nights collection. This tale, uniquely among these translations, also appeared in print - in fact twice, first in 1933 and again in 1947.

The vogue for these contes orientaux had a profound effect on eighteenthcentury Europe. Among those influenced by them was François-Marie Arouet, better known as Voltaire (1694-1778), whose Zadig, ou la destinée, histoire orientale, borrows much from them. First published in Paris in 1748 and quickly translated into all the major languages of Europe, Zadig is found in an Icelandic translation by the clergyman and poet Jón Oddsson Hjaltalín (1749-1835) in Reykjavík, National and University Library of Iceland, Lbs 893 8vo, a miscellany from around the end of the eighteenth century (fig. 8). The translation is based on the Danish translation of Frederik Christian Eilschov (1725-1750), Zadig eller 


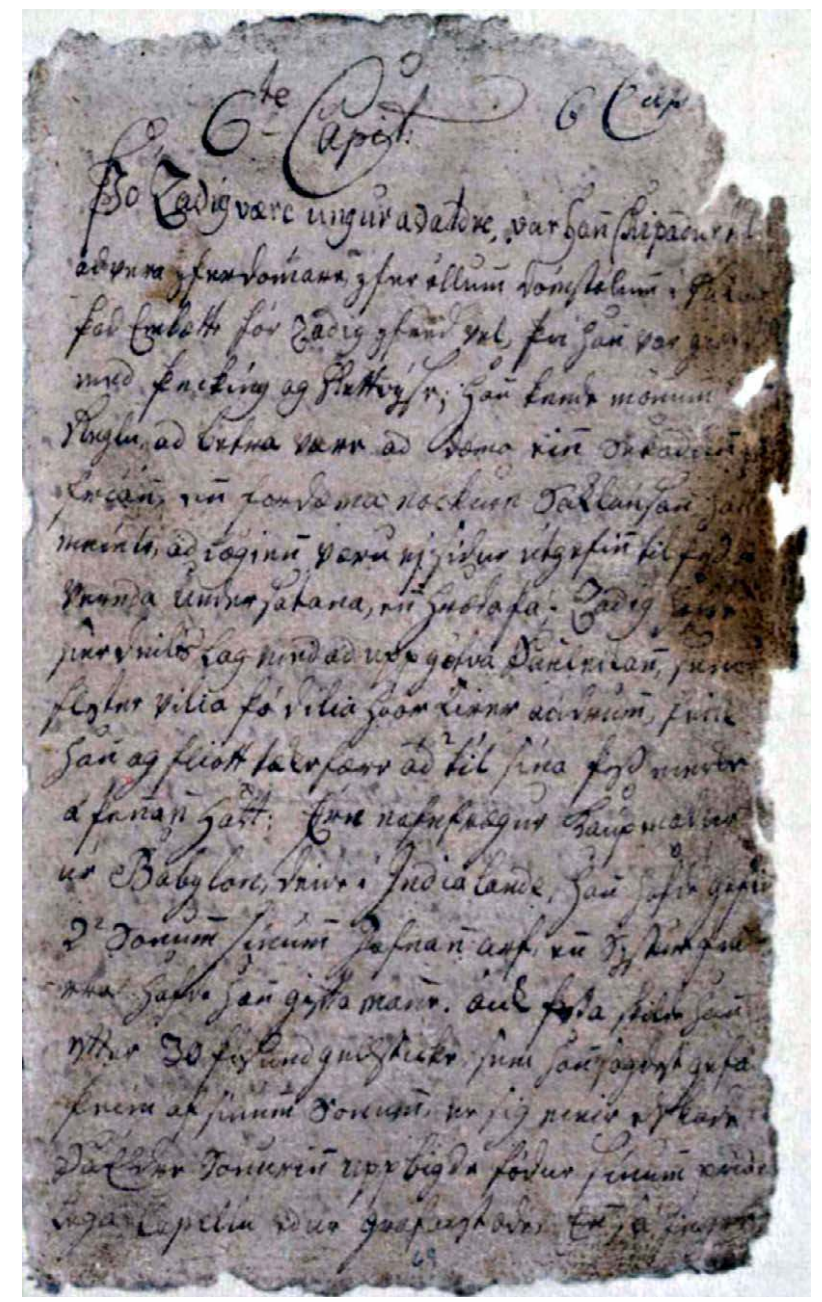

Fig. 8: Reykjavík, National and University Library of Iceland,

Lbs 893 8vo, f. 69r, the beginning of Chapter VI of Jón Oddsson Hjaltalín's translation of Voltaire's Zadig, ca. 1800 (autograph)

Skøbnen: En østerlandsk Historie, published in Copenhagen in 1750 (the first of two Danish translations, the other, by Jens Schelderup Sneedorff, appearing in 1759). It is a reasonably faithful, if slightly abridged, rendering of the Danish text (which is itself somewhat simplified vis-à-vis the French original). There are a couple of significant changes, however: a long passage in chapter VII in which the growing passion felt by Zadig and the Queen for each other is greatly reduced, and a significant omission is found in chapter XI, where an animated debate on the various religions practised by a group of people assembled at the market town of Balzora - which ends with Zadig explaining that whatever they may worship separately they all recognise a supreme being and are therefore 
all of one mind - is reduced to a few sentences, and the question of religion avoided entirely. Presumably the reason for this omission is that the translator, a minister in the Lutheran church, disagreed with its message, that Christianity is no better than any other religion. Given that this is one of basic tenets of deism, a philosophy espoused by Voltaire, this is indeed a significant change. Ironically, this changes the nature of Voltaire's work, removing, as it were, the philosophie from his conte philosophique and bringing it more into line with the contes orientaux of which Zadig is in some ways a pastiche ${ }^{42}$.

\section{Le voyage au centre de la Terre}

I recently encountered a translation of the first part of, for a foreigner at least, that most quintessentially French of works, Jules Verne's Le voyage au centre de la Terre, which was first published in French in 1864. The Icelandic translation, called "Ferð til jarðar-möndulsins" (lit. Journey to the Earth's axis), is found in the paper manuscript Reykjavík, National and University Library of Iceland, Lbs 1631 4to (fig. 9), written in 1869-70 - just three years after the publication of the original - by the clergyman Porleifur Jónsson á Skinnastað (1845-1911). Although I have not yet been able to investigate the translation, it seems likely that it was made directly from the French, as the Danish translation, Rejsen til Jordens Indre, did not appear until 1898. It is hardly surprising that this novel, so popular everywhere, became known in Iceland, given that part of it actually takes place there. What is surprising is that the first complete Icelandic translation was not published until 1944, with a slight modification to the title: Leyndardómur Sncefellsjökuls: För i iður jarðar (The mystery of Snæfellsjökull: Journey to the centre of the Earth).

\section{Conclusion}

Even from this short and superficial review of just a few of the French literary works that washed up on Iceland's shores it should be clear that the hunger for good stories among the Icelanders was such that virtually anything could be turned into a saga or a set of rimur - generally both. In the process, some things were inevitably "lost in translation", both accidentally and deliberately, owing to cultural or linguistic differences. But a good story remained a good story, even if some of its meanings failed to complete the journey.

While some of the works mentioned here were translated directly from French, it was more common for such material to reach Iceland via other languages, primarily Danish - not unnaturally, as Iceland was part of the kingdom of Denmark (from the fourteenth to the twentieth century) and Danish was the foreign language, along with Latin, with which most people were familiar.

42. The Icelandic translation of Zadig is dealt with in DrIsCOLL, 1997, p. 117-22; DrISCOLL, 2006, p. $\mathrm{xxx}-\mathrm{xxxv}$. 


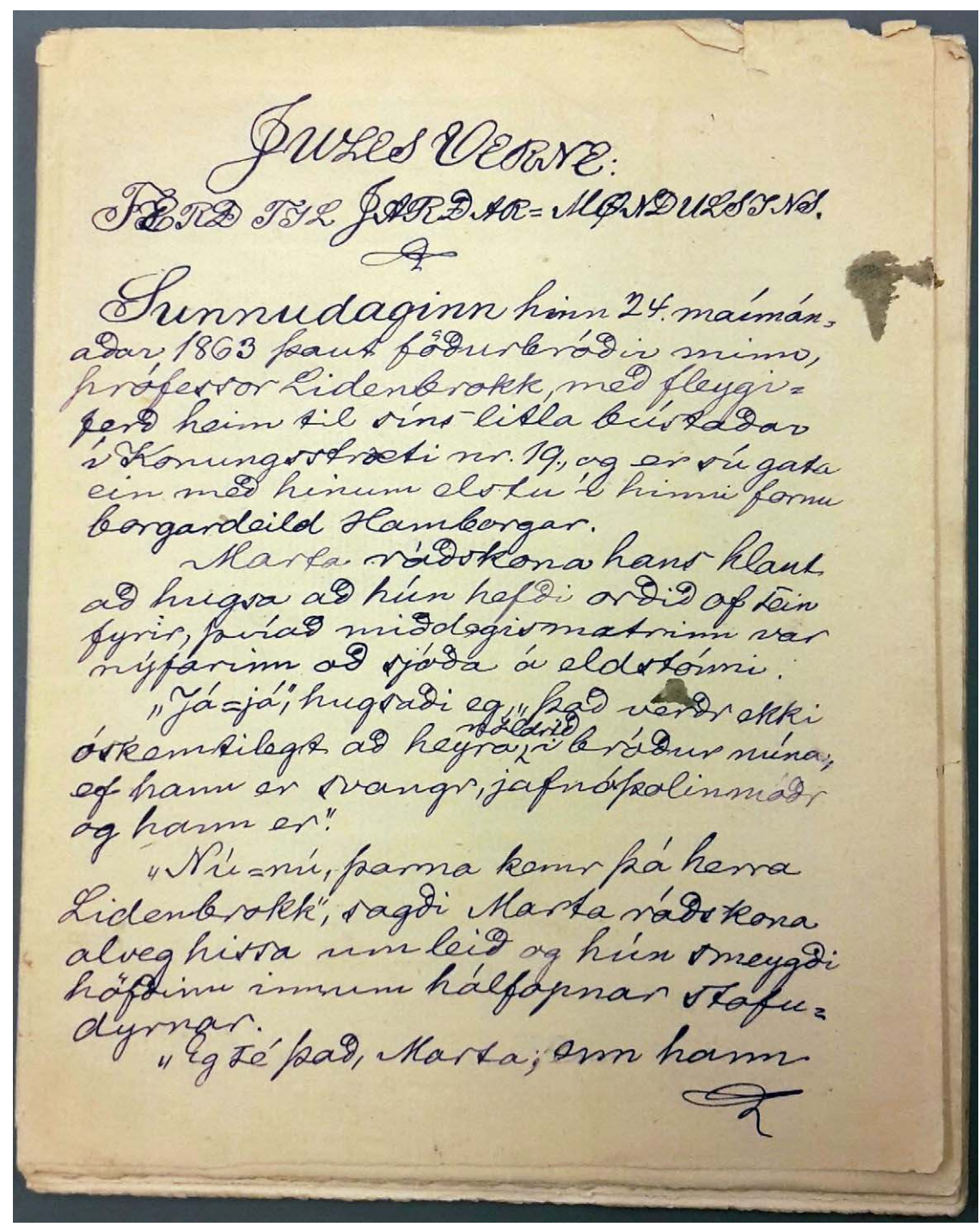

Fig. 9: Reykjavík, National and University Library of Iceland, Lbs 1631 4to, f. 1r, the beginning of Porleifur Jónsson's translation of Jules Verne's Le voyage au centre de la Terre, copied in 1869-70 (autograph)

It is striking how much reached Iceland, demonstrating that despite its geographical location on the edge of the inhabitable world, Iceland was far from isolated. It is also striking how quickly things reached Iceland, often within a generation. Voltaire's Zadig first appeared in French in 1748; it was translated into Danish just two years later, and into Icelandic by the end of the century. And Florian's story "Sélico" appeared in print in Iceland just 26 years after its original 
publication in France. The wait has been longer for Proust's $\grave{A}$ la recherche $d u$ temps perdu -84 years (and that's just the first volume) ${ }^{43}$.

\section{Bibliography}

BARnes, Geraldine, "Riddarasögur (translated)", in Medieval Scandinavia: An Encyclopedia, Philip Pulsiano and Kirsten Wolf (eds.), New York, Garland, 1993, p. 531-533.

BARnES, Geradine, “Tristan in Late Medieval Norse literature: Saga and Ballad”, in Tristan und Isolt im Spätmittelalter: Vorträge eines interdisziplinären Symposiums vom 3. bis 8. Juni 1996 an der Justus-Liebig-Universität Gießen, Xenja von ErtzdorfF (ed.), Amsterdam, Rodopi, 1999, p. 373-396.

BARnes, Geraldine, "The Tristan Legend", in The Arthur of the North: The Arthurian legend in the Norse and Rus' realms, Marianne Kalinke (ed.), Cardiff, University of Wales Press, 2011, p. 61-76.

Bornholdt, Claudia, “The Old Norse-Icelandic Transmission of Chrétien de Troyes's Romances: Ívens saga, Erex saga, Parcevals saga with Valvens páttr”, in The Arthur of the North: The Arthurian Legend in the Norse and Rus' Realms, Marianne Kalinke (ed.), Cardiff, University of Wales Press, 2011, p. 98-122.

Cederschiöld, Gustav and WulfF, Fredrik (eds.), Versions nordiques du fabliau français Le Mantel mautaillié, Lund, Gleerup, 1877.

Driscoll, Matthew James, “The Cloak of Fidelity: Skikkjurimur, a Late-Medieval Icelandic Version of Le Mantel mautaillié", in The Arthurian Yearbook 1, Keith Busby (ed.), New York, Garland, 1991, p. 107-133.

Driscoll, Matthew James, The Unwashed Children of Eve: The production, Dissemination and Reception of Popular Literature in Post-Reformation Iceland, Enfield Lock, Hisarlik Press, 1997.

Driscoll, Matthew James, "Late Prose Fiction (lygisögur)", in A Companion to Old Norse-Icelandic Literature and Culture, Rory MCTURK (ed.), Oxford, Blackwell, 2005, p. 190-204.

Driscoll, Matthew James, "Inngangur”, Fjórar sögur frá hendi Jóns Oddssonar Hjaltalín: Sagan af Marroni sterka, Ágrip af Heiðarvíga sögu, Sagan af Zadig, Fimmbræðra saga, Reykjavík, University of Iceland Press, 2006, p. vii-lxxiv.

Driscoll, Matthew James, “Arthurian Ballads, Rímur, Chapbooks and Folktales”, in The Arthur of the North: The Arthurian Legend in the Norse and Rus' Realms, Marianne Kalinke (ed.), Cardiff, University of Wales Press, 2011, p. 168-195.

Driscoll, Matthew James, “'Um gildi gamalla bóka’: Magnús Jónsson í Tjaldanesi und das Ende der Handschriftenkultur in Island", in Text - Reihe - Transmission: Unfestigkeit als Phänomen skandinavischer Erzählprosa 1500-180o, Jürg GLAUSER and Anna Katharina Richter (eds.), Beiträge zur Nordischen Philologie 42, Tübingen and Basel, Franke, 2012, p. 255-282.

43. Pétur Gunnarsson's translation of Du côté de chez Swann (Îleit að glötuðum tíma: leiðin til Swann) came out in 1997. 
Driscoll, Matthew James, “The Long and Winding Road: Manuscript Culture in Late Pre-Modern Iceland", in White Field, Black Seeds: Nordic Literacy Practices in the Long Nineteenth Century, Anna Kuismin and M. J. Driscoll (eds.), Helsinki, Suomalaisen Kirjallisuuden Seura, 2013, p. 50-63.

EINARsson, Bjarni, Skáldasögur: Um uppruna og eðli ástaskáldasagnanna fornu, Reykjavík, Menningarsjóður, 1961.

Eriksen, Stefka G., "Courtly Literature”, in The Routledge Research Companion to the Medieval Icelandic Sagas, Ármann Jakobsson and Sverrir Jakobsson (eds.), London, Routledge, 2017, p. 59-73.

Finlay, Alison, "Intolerable Love: Tristrams Saga and the Carlisle Tristan Fragment”, Medium revum, 73.2, 2004, p. 205-224.

Francini, Marusca, “The 'Saga af Tristram ok Ísodd': An Icelandic Reworking of 'Tristrams Saga', in The Garden of Crossing Paths: The Manipulation and Rewriting of Medieval Texts, Marina Buzzoni and Massimiliano BAmpi (eds.), Venezia, Università Ca' Foscari, 2005, p. 249-271.

Glauser, Jürg, "Romance (translated riddarasögur)", in A Companion to Old NorseIcelandic Literature and Culture, Rory MCTuRk (ed.), Oxford, Blackwell, 2005, p. $372-387$.

GuĐmundsson, Finnbogi, “Frá Hallgrími Scheving”, Árbók Landsbókasafns Íslands 26, 1969, p. 156-209.

Hermannsson, Halldór, "Bibliographical Notes”, Islandica 29, Ithaca NY, Cornell University Press, 1942.

Hughes, Shaun, "Late Secular Poetry", in A Companion to Old Norse-Icelandic Literature and Culture, Rory McTurk (ed.), Oxford, Blackwell, 2005, p. 205-222.

Kalinke, Marianne E., King Arthur, North-by-Northwest: The Matière de Bretagne in Old Norse-Icelandic Romances, Bibliotheca Arnamagnæana 37, Copenhagen, Reitzel, 1981.

KALINKe, Marianne E., “Norse Romance (riddarasögur)”, Old Norse-Icelandic Literature: A Critical Guide, Carol Clover and John Lindow (eds.), Islandica 45, Ithaca NY, Cornell University Press, 1985, p. 216-264.

Kalinke, Marianne E. (ed.), Mottuls saga, Editiones Arnamagnæanæ B 30, Copenhagen, Reitzel, 1987.

Kalinke, Marianne E., "Sources, Translations, Redactions, Manuscript Transmission”, in The Arthur of the North: The Arthurian Legend in the Norse and Rus' Realms, Marianne Kalinke (ed.), Cardiff, University of Wales Press, 2011, p. 22-47.

KJÆR, Jonna, “Tristan og Indiana eller 'Lykkens tumlebold': Fortællinger om Tristan og Isolde i Norden”, in Michelanea: Humanisme, litteratur og kommunikation. Festskrift til Michel Olsen i anledning af hans 60-årsdag den 23. april 1994, Aalborg, Center for sprog og interkulturelle studier, 1994, p. 81-87.

KJÆR, Jonna, “Les Rímur af Tístran og Indíönu (1831) de Sigurður Breiðfjörð - une version islandaise du mythe de Tristan et Iseut", in Tristan und Isolde: Unvergängliches Thema der Weltkultur, XXX. Jahrestagung des Arbeitskreises 'Deutsche Literatur des Mittelalters', 27. September - 1. Oktober 1995, Wodan 57, Greifswald, Reineke-Verlag, 1996, p. 141-154. 
Kramarz-Bein, Susanne, "Die jüngere altisländishe Tristram saga ok Ísoddar und ihre literarische Tradition", in Erzählen im mittelalterlichen Skandinavien, Robert Nedoma et al. (ed.), Wien, Praesens, 2000, p. 21-45.

Larrington, Carolyne, “The Translated Lais", in The Arthur of the North: The Arthurian Legend in the Norse and Rus' Realms, Marianne Kalinke (ed.), Cardiff, University of Wales Press, 2011, p. 77-97.

LEACH, Henry Goddard, Angevin Britain and Scandinavia, Cambridge MA, Harvard University Press, 1921.

Maclean, Helen Susan, “The Old Norse Parceval”, Bulletin bibliographique de la Société Internationale Arthurienne 24, 1972, p. 209-210.

Ólafsson, Davíð, "Post-medieval Manuscript Culture and the Historiography of Texts", in Mirrors of Virtue: Manuscript and Print in Late Pre-modern Iceland, Margrét EggertsdótTir and Matthew James Driscoll (eds.), Copenhagen, Museum Tusculanum Press, 2017, p. 1-30.

Ólason, Vésteinn, The Traditional Ballads of Iceland: Historical Studies, Reykjavík, Stofnun Árna Magnússonar, 1982.

PORGILSson, Pórhallur, Drög að skrá um ritverk á íslenzku að fornu og nýju af latneskum eða rómönskum uppruna I: Frakkland, Reykjavík, Landsbókasafn Îslands, 1954.

Reichert, Hermann, “King Arthur's Round Table: Sociological Implications of its Literary Reception in Scandinavia", in Structure and Meaning on Old Norse Literature, John Lindow, Lars LönNRoth and Gerd Wolfgang Weber (eds.), Odense, Odense University Press, 1986, p. 394-414.

Rubow, Paul V., "De islandske Familieroman”, Smaa kritiske Breve, København, Levin \& Munksgaard, 1936, p. 7-25; originally published in Tilskueren 1928.

Schach, Paul, "Some Observations on Tristrams Saga”, Saga-book of the Viking Society 15, 1957-1961, p. 102-129.

SchaCh, Paul, “The Saga af Tristram ok Ísodd: Summary or Satire?”, Modern Language Quarterly 21, 1960, p. 336-352.

SCHACH, Paul, "Tristan and Isolde in Scandinavian Ballad and Folklore", Scandinavian Studies 36, 1964, p. 281-297.

Schach, Paul, "Some Observations on the Translations of Brother Robert", in Les Relations littéraires franco-scandinaves au Moyen Âge, Actes du Colloque de Liège, Paris, Les Belles Lettres, 1975, p. 117-135.

SCHACH, Paul, “Tristrams saga ok Ýsoddar as Burlesque”, Scandinavian Studies 59, 1987 , p. 86-10o.

Schlauch, Margaret, Romance in Iceland, Princeton NJ, Princeton University Press, 1934.

Sigmundsson, Finnur, Rímnatal I-II, Reykjavík, Rímnafélagið, 1966.

Sigurjónsson, Sveinbjörn, “Inngangur”, Núma rímur, $3^{\text {rd }}$ ed., Reykjavík, Snæbjörn Jónsson, 1937, p. xi-lxiv.

STEINGRÍMSson, Sigurgeir, "Tusen och en dag: En sagosamlings vandring från Orienten till Island", Scripta Islandica 31, 1980, p. 54-64.

SveINsson, Einar Ólafur, Verzeichnis isländischer Märchenvarianten, mit einer einleitenden Untersuchung, FF Communications 83, Helsinki, Suomalainen Tiedeakatemia, 1929. 
Thorleifsdóttir, Hanna Steinunn, "Le Chevalier au lion: un texte dénudé en traduction? Le cas d'Ívens saga", in Pratiques de Traduction au Moyen Âge/ Medieval Translation Practices, Peter Andersen (ed.), Copenhagen, University of Copenhagen, Museum Tusculum Press, 2004, p. 22-28.

Thorleifsdóttir, Hanna Steinunn, "Dialogue in the Icelandic Copies of Ívens saga", in Übersetzen im skandinavischen Mittelalter, Vera JohanterwaGe and Stefanie WürTh (eds.), Wien, Fassbaender, 2007, p. 167-176. 